\title{
Water Management Systems and Rice Yields Under Humid Tropical Conditions in Puerto Rico ${ }^{1,2}$
}

\author{
Servando Silva, José Vicente-Chandler and Fernando Abruña ${ }^{3}$
}

\section{ABSTRACT}

High rice yields of $7,020 \mathrm{~kg}$ of rough rice/ha were produced when seed was disced into the soil followed by permanent flooding. Similarly high yields of $6,830 \mathrm{~kg} / \mathrm{ha}$ were produced with the same planting method when $5 \mathrm{~cm}$ of irrigation water was applied weekly without permanent flooding. When pregerminated rice was seeded in permanently flooded land, however, significantly lower yields of $5,300 \mathrm{~kg} /$ ha were obtained, probably because of several conditions: the adverse effects of algae, a less even stand of seedlings caused by floating germinated seed, earlier lodging of the plants, and also possibly, heavier losses of fertilizer nitrogen.

\section{INTRODUCTION}

Considerable research has been conducted on intensive rice production in Puerto Rico by Lozano and Abruña $(3,4,5,6)$, Abruña and Lozano $(1,2)$, Ramirez, et al. (7), Silva and Vicente-Chandler (8), and VicenteChandler et al. (9) including studies on fertilization, varieties, planting season, evapotranspiration, and production costs.

In irrigation studies, Silva and Vicente-Chandler (8) found that evapotranspiration with flooded rice averaged $.61 \mathrm{~cm}$ daily under conditions typical of the humid north coast of Puerto Rico. Abruña and Lozano (2) found that when irrigation was applied only every 10 days at Gurabo, subjecting the rice to considerable moisture stress over relatively short periods, 8 short grain varieties produced similar yields, averaging 3,900 $\mathrm{kg}$ of rough rice/ha; 8 medium grain varieties averaged $3,670 \mathrm{~kg} / \mathrm{ha}$ with varieties Brazos and Vista averaging the highest yields of $5,264 \mathrm{~kg} / \mathrm{ha}$; and 9 long grain varieties averaged $3,640 \mathrm{~kg} / \mathrm{ha}$ with varieties Lebonnet, Venus, Galaxia, Gema, and Morado Criollo averaging 4,567 kg/ha.

The present study was designed to determine the effect of three water management systems on yields of intensively managed rice under conditions typical of the humid region of Puerto Rico.

\footnotetext{
${ }^{2}$ Manuscript submitted to Editorial Board August 30, 1982.

${ }^{2}$ This paper covers work carried out cooperatively between ARS-USDA and the Agricultural Experiment Station, College of Agricultural Sciences, Mayagüez Campus, University of Puerto Rico.

${ }^{3}$ Research Technician and Soil Scientists, ARS-USDA, Agricultural Experiment Station, Río Piedras, P.R.
} 


\section{MATERIALS AND METHODS}

The experiment was conducted on a Toa clay loam (Mollisols) at Río Piedras at an elevation of about $50 \mathrm{~m}$. Treatments were replicated six times with each plot $3 \mathrm{~m}^{2}$ surrounded by a small dike.

Variety Brazos (medium grain) was planted in all plots at the rate of $100 \mathrm{~kg} / \mathrm{ha}$. Fertilizer was applied at the rate of $500 \mathrm{~kg} / \mathrm{ha}$ of $10-5-15$ at planting, followed by $60 \mathrm{~kg}$ of N/ha applied as urea 6 weeks later. Propanil was applied at the rate of $1.5 \mathrm{~kg} / \mathrm{ha}$ about 3 weeks after planting when required to control weeds. Plots were sprayed twice during the growing season to control insects and diseases. The experiment was planted March 3, 1982.

The crop was harvested when moisture content of the grain was about $20 \%$. It was dried to $12 \%$ moisture, and trash was removed with an air current. Yields were expressed in $\mathrm{kg}$ of rough rice/ha.

Treatments were as follows: A) Pregerminated rice seeded in permanently flooded soil; B) dry seed disced into fairly dry soil followed by intermittent irrigation as required, and permanently flooded 3 weeks after planting; C) dry seed disced into fairly dry soil, and $5 \mathrm{~cm}$ of water applied weekly; no flooding.

\section{RESULTS AND DISCUSSION}

The following tabulation shows that high yields, $7,020 \mathrm{~kg}$ of rough rice/ha, were produced when the seed was disced into the soil followed by intermittent irrigation as required for 3 weeks and then by permanent flooding or by $5 \mathrm{~cm}$ of irrigation water applied weekly with no flooding $(6,830 \mathrm{~kg} / \mathrm{ha})$. Under hot tropical conditions, periodic irrigation is required at shorter intervals than in the cool spring months of temperate regions.

\section{Treatment}

Pregerminated rice seeded in permanently Yields of rough rice $\mathrm{kg} / \mathrm{ha}$ flooded land $5,300 \mathrm{~b}^{4}$

Dry seed disced into fairly dry soil followed by intermittent irrigation as required and permanently flooded 3 weeks after planting Dry seed disced into fairly dry soil and $5 \mathrm{~cm}$ of water applied weekly, no flooding $7,020 \mathrm{a}$ 6,830 a

\footnotetext{
${ }^{4}$ Numbers followed by one or more letters in common, do not differ significantly at the $\mathrm{P}=.05$ level according to Duncan's multiple range test.
} 
Significantly lower yields, $5,300 \mathrm{~kg} / \mathrm{ha}$, were produced by seeding pregerminated rice in permanently flooded land.

A rather dense growth of algae occurred in the plots that were flooded before planting and probably adversely affected the young rice plants. This problem is much more important in the tropics, where irrigation water is much warmer and algae grow faster than in young rice fields in the spring in temperate regions. In addition, stand was less uniform because of some of the seed floated soon after germination and the plants lodged at an earlier stage probably resulting in lower yields. Also, water temperatures taken in the plots when the rice seedlings were small were as high as $32^{\circ} \mathrm{C}$ in the afternoon of hot sunny days; this heat could adversely affect very young seedlings. Furthermore, heavier losses of the fertilizer nitrogen applied at planting could have occurred during the first weeks when the rice plants took up little nitrogen.

The data presented indicate that under hot humid tropical conditions in Puerto Rico, rice seed should whenever possible, be disced into the soil followed by periodic irrigation as required, and by permanent flooding about 3 weeks after planting.

Flooded fields should be seeded when the weather does not permit proper preparation of the land. In this case, the water should be removed about 3 days after planting, or immediately if large quantities of seedlings start to float; intermittent irrigation should follow as required; and permanent flooding, about 3 weeks after planting. If the field is kept flooded there is better control of weeds and of some insects but algae can be a serious problem and floating of germinated seed can result in a less uniform stand. Also, water level must be uniform and not more than about $8 \mathrm{~cm}$ deep. Otherwise, the young rice seedlings may grow spindly.

The data show that high yields of rice can be obtained with only intermittent irrigation provided weeds are properly controlled. Such a system permits growing rice in areas where the traditional method of flooding is not possible because soils are too porous or the terrain is too steep or because of water shortage. This system saves water by reducing losses caused by percolation; it makes possible a better use of rainfall, but on the other hand it requires more use of herbicides.

\section{RESUMEN}

Se compararon distintos sistemas de regar arrozales cultivados intensivamente.

Los rendimientos más altos se obtuvieron cuando la semilla se sembró en terreno seco, se tapó con tierra y enseguida se regó intermitentemente por 3 semanas, y luego se anegó permanentemente $(7,020 \mathrm{~kg}$ de arroz en cáscara/ha).

Se obtuvo una producción más baja, 5,300 kg/ha, cuando se sembró 
semilla pregerminada en terreno inundado permanentemente. Este sistema puede practicarse cuando la condición del terreno no permite usar el sistema anterior. En tal caso es aconsejable desaguar los campos unos 3 días después de la siembra o inmediatamente, si mucha de la semilla flotase. En este caso, se debe regar a intervalos durante aproximadamente 3 semanas y luego inundar los campos permanentemente. Si los campos se mantienen inundados después de sembrar se pueden combatir mejor los yerbajos y algunos insectos, pero las algas pueden constituir un serio problema. Además, si flota mucha de la semilla la plantación no será uniforme. No deben mantenerse más de unos $8 \mathrm{~cm}$ de agua sobre el terreno mientras las plantitas se desarrollan.

Se obtuvo un buen rendimiento $6,830 \mathrm{~kg} / \mathrm{ha}$, regando intermitentemente durante todo el ciclo de producción. Este sistema permite sembrar arroz en terrenos que no se pueden inundar debido a su topografía o porosidad o donde no hay agua suficiente, ya que requiere menos agua. Sin embargo, es necesario combatir los yerbajos con más frecuencia.

\section{LITERATURE CITED}

1. Abruña, F. and Lozano, J., 1974. Effect of season of the year on yields of 13 varieties of rice growing in the humid region of Puerto Rico, J. Agric. Univ. P.R. 58 (1): 11-7.

2. - - and - - 1977. Productivity of 25 varieties of rice grown under conditions of limited moisture, J. Agric. Univ. P.R. 61 (1): 1-5.

3. Lozano, J. and Abruña, F., 1977. Effect of planting season on yields of eight shortgrain varieties of rice under irrigation, J. Agric. Univ. P.R. 61 (1): 6-10.

4. - - and - - 1981. Nitrogen rates in single and split applications and yield of flooded rice, J. Agric. Univ. P.R. 65 (1): 35-42.

5. - - and —-, 1982. Effect of planting methods and seeding rates on rice yields, J. Agric. Univ. P.R. 66 (3): 194-99.

6. - - and - -1982 . Season of the year and yields of seven medium grain varieties of rice. J. Agric. Univ. P.R. 66 (3): 188-93.

7. Ramírez, C. T., Abruña, F., Lozano, J. and Vicente-Chandler, J., 1975. Effect of fertilization on yields of three varieties of rice at two locations in Puerto Rico, J. Agric. Univ. P.R. 59 (1): 1-4.

8. Silva, S. and Vicente-Chandler, J., 1982. Water use by flooded rice in Puerto Rico, J. Agric. Univ. P.R. 66 (3): 181-87.

9. Vicente-Chandler, J., Abruña, F., Lozano, J., Silva, S., Rodríguez, A. y Ramírez, C. T., 1977. Cultivo intensivo y perspectivas del arroz en Puerto Rico, Esta. Exp. Agric. Univ. P.R., Bol. 250. 